\title{
AERoElastic EXPERIMENTS With Measurement OF THE KinematiC Properties BaSED ON OPTICAL Methods
}

\author{
Štěpán Chládek ${ }^{1}$; Igor Zolotarev ${ }^{2}$ \\ Institute of Thermomechanics AS CR, v. v. i., Department of Dynamics and Vibrations, \\ Dolejškova 1402/5, 18200 Praha 8, Czech Republic \\ e-mail: ${ }^{1}$ chladek@it.cas.cz; ${ }^{2}$ igor@it.cas.cz
}

\begin{abstract}
A credible aeroelastic experiment deals with variables important for the description of dynamics of aeroelastic phenomena. These variables include, in particular, position, velocity, acceleration and the acting forces. This paper describes the measurement of kinematic properties based on an optical method, where the optical target is captured with a high frequency camera. Based on the evaluated position, there have been derived velocity and acceleration. The acceleration has been compared with the data measured with the accelerometer. A great advantage of the presented approach is the minimal influence of the measured system over the sensors and the possibility of redundant measurement as well. The contribution of the redundant measurement has been confirmed during an experiment performed on an aeroelastic experimental stand with the profile NACA 0012.
\end{abstract}

\section{Introduction}

Aeroelasticity describes the interaction among fluids and solid objects. The fluid flow can affect both the position and the deformation of the solid object, and consequently these changes of the fluid flow can be influenced. Aeroelastic experiments are focused mainly on the response of the solid object to the fluid flow as a function of a fluid velocity. A widespread topic is the measurement of instability of the solid object and assessment of the conditions when the instability occures. These results are often compared with the numerical solution [1]. In the aeroelastic experiments the kinematic and dynamic properties of the solid body should be measured. Evaluation of aerodynamic forces is often based on the total pressure measurement and the related interferogramms evaluation [3]. Another method of the forces measurement is based on the tensometric measurement. The tensometric sensors have to be calibrated to the acting forces. Based on this feature, a straight calibration of force against displacement has been introduced [2]. Considering the mentioned papers, it can be concluded that a credible measurement of kinematic quantities may be a base of a complex aeroelastic experiment and the results then provide valuable data for the further research.

\section{$1 \quad$ Features of optical measurements}

Optical measurements of the position are represented by a range of methods with a different approach and some common features. One of those features is the contactless measurement. It can be advantageous when the experiments are placed in the wind tunnel, which has to be hermetically closed. Another advantage of the contactless measurement is the drop out of the cables to sensors, which can influence the damping of the system under tests (SUT) significantly. The minimal influence of the SUT is very important in the aeroelastic experiments especially with the wings, which are often very subtile. The optical measurements either do not affect the SUT (laser vibrometres, optical position sensors), or affect the SUT at minimum (low weight of optical targets, which are tracked with a high 
speed camera). The configuration of the experiment depends on the measuring devices. This paper deals with a high frequency camera, which is placed perpendicularly to the measured motion.

\section{$1.1 \quad$ Optical targets}

If an optical method is based on the measurement with a high frequency camera, the object of interest can be measured directly [4], or an optical target can be used. The advantage of optical targets is based on the high contrast and the resulting easiness of computer processing with a high precision. The targets can be easily prepared and modified with a common graphical programme. The basic idea is to create black circles in some planar configuration and to plot them on a white sheet of paper. Any common office printer gives a sufficient degree of quality; moreover, the larger the circles are, the more precise results are obtained. This assumption is based on the fact that the boundary circle is a plot with a lower accuracy and more points inside the circle influence the resulting position more. The optical points on the targets have to be circles to be invariant to rotation. The evaluation of their position is related to the coordinate system of the camera.

\subsection{Redundancy for a higher accuracy}

The more degrees of freedom (DOF) have to be investigated, the more optical targets have to be measured. In the case of one DOF just one point is sufficient; in the case of two DOF right two points are sufficient, etc. Redundancy means that more points than the number of DOF is measured and consecutively evaluated. The points over the number of DOF are used to specify some condition for a higher accuracy. In the experiments focused on wings problematics, there are often measured two degrees of freedom of the wing, so the optical target with two points can be correctly used. Nevertheless, the optical target with three points can be used as well and the redundant condition is introduced with a constant configuration of the three points. The measurement is divided into two parts, when in the first one the optical target is measured in a constant position and in the second one, the optical target is being captured in motion. Finally, the data are evaluated with the effort of placement of the initial configuration of the target to the moving position with the minimal error. The idea is based on the assumption that the target in a constant position can be measured with a higher accuracy than the moving optical target; during the motion the points on the optical target are captured with a comparable error. In the case of three points, which are creating a triangle, idea is to find the center of gravity of that triangle (Fig. 1). The kinematic transformation can be expressed as $\left\{A_{N}, B_{N}, C_{N}\right\}=T .\left\{A_{1}, B_{1}, C_{1}\right\}$ with the transform matrix T:

$$
T=\left[\begin{array}{ccc}
\cos (\varphi) & -\sin (\varphi) & x \\
\sin (\varphi) & \cos (\varphi) & y \\
0 & 0 & 1
\end{array}\right]
$$

where $\varphi$ is the mean value of the angle of rotation and $x, y$ is the translation of the centroid in the $x$ and $y$ direction, respectively.

\subsection{Derivation of velocity and acceleration}

Once the position has been measured, the velocity and acceleration can be derived. Because the position is measured in discrete samples, the time derivative of the position is replaced with time difference. Central difference schemes with a different order of accuracy [5] are appropriate to be used; a general difference of $N-t h$ order can be written as 


$$
f^{\prime}\left(x_{i}\right)=\frac{1}{h} \sum_{k=1}^{(N-1) / 2} c_{k}\left(f\left(x_{i+k}\right)-f\left(x_{i-k}\right)\right)
$$

where $N$ has to be an odd number and $c_{k}$ are the coefficients of the corresponding order. Basic different methods, such as backward and forward Euler methods can be applied as well, yet due to their low order of accuracy and offline evaluation there is no reason to use them.

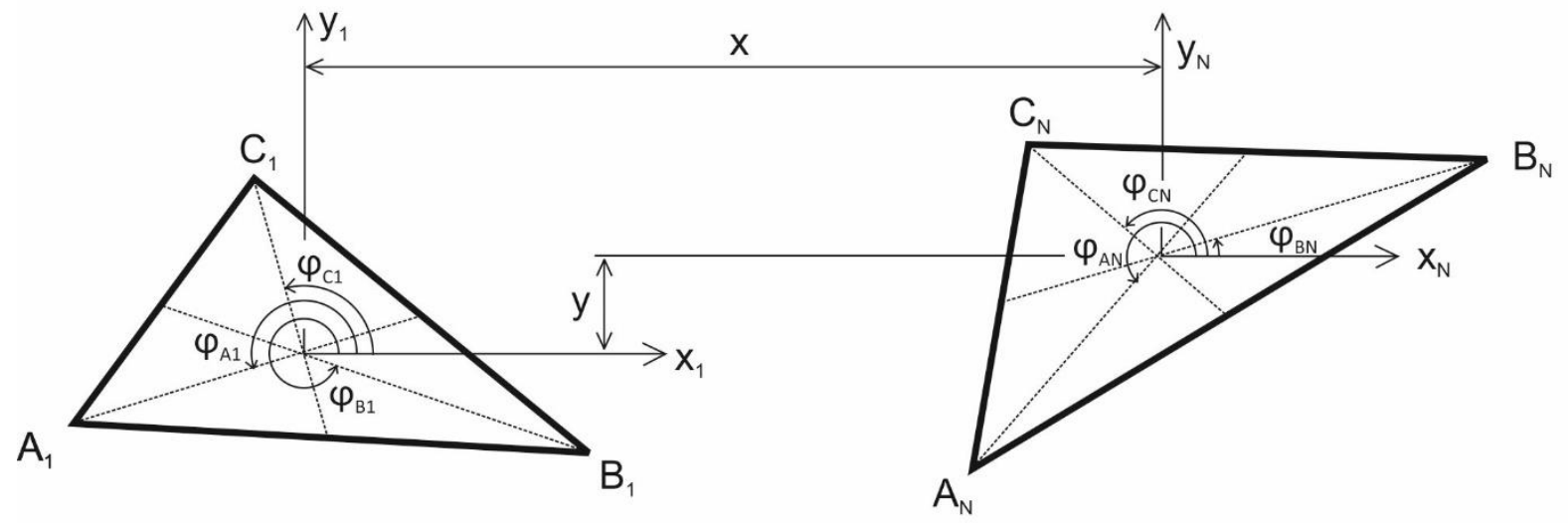

Source: Own.

Fig. 1: The basic idea of the redundant optical measurement is to fit an original configuration to an arbitrary position with a minimal error.

\section{$2 \quad$ Results and discussion}

The equipment of the experiment consists of the compact digital camera Redlake MotionPro X3 with the lens Nikon $60 \mathrm{~mm}$ f/2.8D AF Micro. Two additional halogen lamps were used for the increase of light intensity, each with $500 \mathrm{~W}$ power supply. The camera was used for high speed motion analysis, where the instantaneous position was registered. The lens has a fixed focus with the length $f=60 \mathrm{~mm}$. The native resolution of the sensor is 1280x1024 pixels with the pixel size $12 \mu \mathrm{m}$. The error of the method can be expressed as a function of the equipment and the experiment configuration. The equation for the resolution $r[\mu m]$ of the method can be derived in the basic form as

$$
r=\frac{d}{f} p_{s}
$$

where

$d[\mathrm{~mm}]$ is the SUT to lens distance,

$f[\mathrm{~mm}]$ is the length of the focus, and

$p_{s}[\mu m]$ is the pixel size.

The experiments were divided into three parts. In the first part the accelerometer calibrator was used due to the fact that the velocity and position can be calibrated as well. In the second part the shaker was used for the measurement of different exciting frequencies. In the last part we performed the measurements focused on the impulse response of the aeroelastic stand with the profile NACA0012. The free oscillations were measured in a zero fluid velocity. The programmes for the evaluation of the optical targets were created in the software Matlab/Simulink. The evaluation was divided into three following steps. In the first one, the pixels with the color under the defined threshold were detected. In the second one, the pixels related to the same black circle were determined. In the last step, the center of the circle was computed and saved. 


\subsection{Experiments with the calibrator}

As the calibrator, the decision was to use the accelerometer calibrator Brüel \& Kjær 4294, which is a device with a high precision originally used for calibration of accelerometers. The advantage of the mentioned device is the feedback control based on the crystal, which enables the calibration of the accelerometers with different weights. Position and velocity can be calibrated as well. Equations for the position, velocity and acceleration calibration have been derived on the basis of the manufacturer data sheet:

$$
x=A \cdot \sin \left(2 \pi f_{c} t\right), \dot{x}=2 \pi f_{c} A \cdot \cos \left(2 \pi f_{c} t\right), \ddot{x}=-\left(2 \pi f_{c}\right)^{2} A \cdot \sin \left(2 \pi f_{c} t\right),
$$

where $A=14.142 \mu \mathrm{m}$ is the amplitude of the position, $f_{c}=159.15 \mathrm{~Hz}$ is the calibrating frequency and $t$ denotes the time. The accelerometer was replaced with an optical target, which was captured with a high frequency camera and the kinematic properties were measured. The sampling frequency of the camera was set up to $f_{s}=7800 \mathrm{~Hz}$ and the shutter time to $t=30 \mu \mathrm{s}$. The evaluated position is shown in Fig. 2. From the data in the graph it can be concluded that the position is within the calibrating frequency $f_{c}$ measured with the accuracy $\pm 2 \mu m$.

The velocities were computed from the position using the central difference scheme (2) of orders $N=\{2,3,4,5\}$ and the results were filtered using the $2^{\text {nd }}$ order Butterworth low pass filter with the cutoff frequency $f_{c u t}=500 \mathrm{~Hz}$. The results are compared to the theoretical value and they are demonstrated in Fig. 3. The acceleration was computed from the velocities with the identical difference schemes and the results are shown in Fig. 4. The computed accelerations have been filtered as well. The overall error of the measurement is less than $\pm 1 \mathrm{~mm} . \mathrm{s}^{-1}$ and $\pm 2,5 \mathrm{~m} . \mathrm{s}^{-2}$ in the case of velocity and acceleration, respectively. The errors were computed as differences of measured and theoretical values given by (4). The accelerometer measured the acceleration with higher accuracy than the optical methods, as can be seen in Fig. 4.

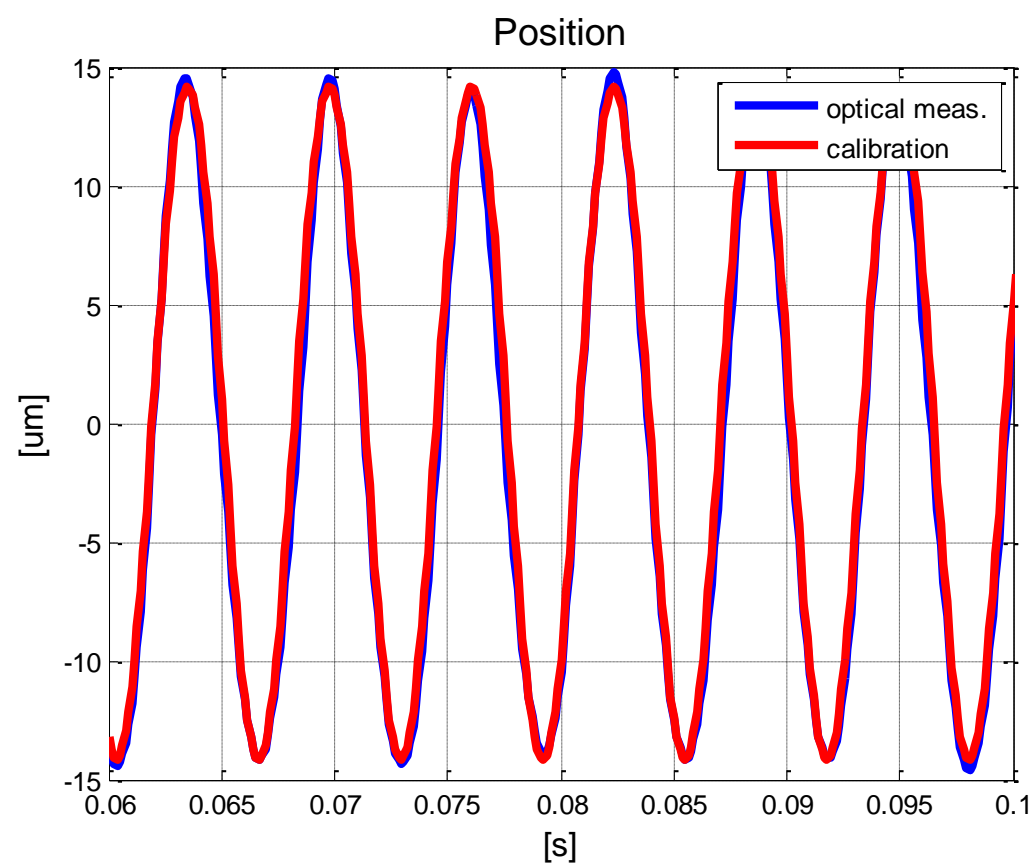

Source: Own.

Fig. 2: The calibration (red line) and the position evaluated from the optical measurement (blue line) 


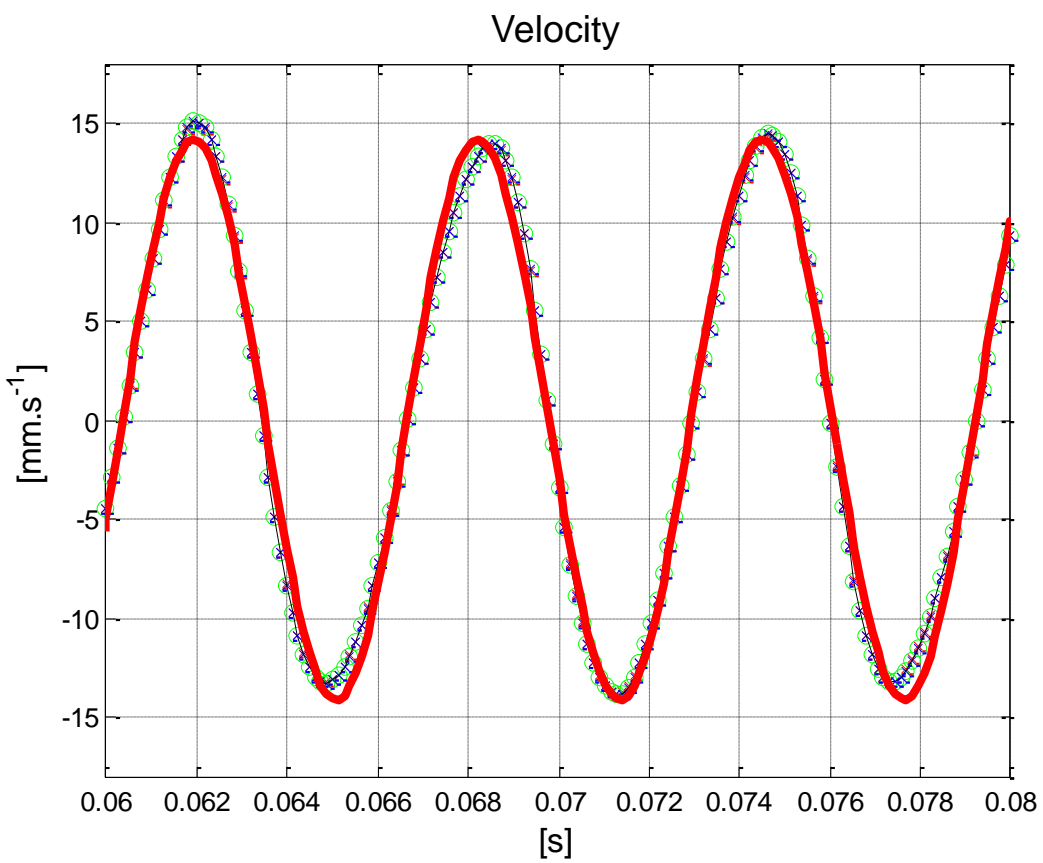

Source: Own.

Fig. 3: The velocities computed from the position using different central difference schemes compared with the calibration velocity (red line)

The details of both velocities and accelerations computed with central difference schemes (2) from the position are presented in Fig. 5. Although the differences are not clear in the graphs, the higher order of the method leads to the more accurate solution.

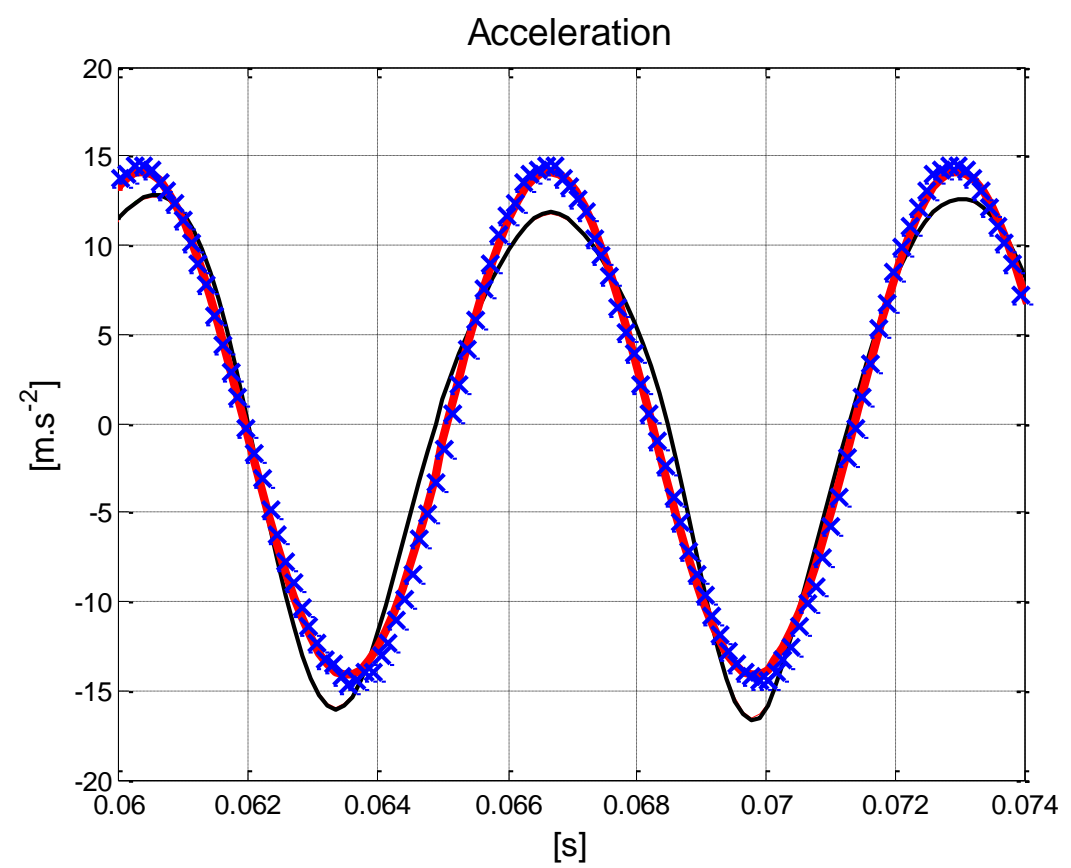

Source: Own.

Fig. 4: The acceleration computed from the velocities using the different central difference schemes compared with the calibration acceleration (red line) and the acceleration measured with an accelerometer (blue crosses) 

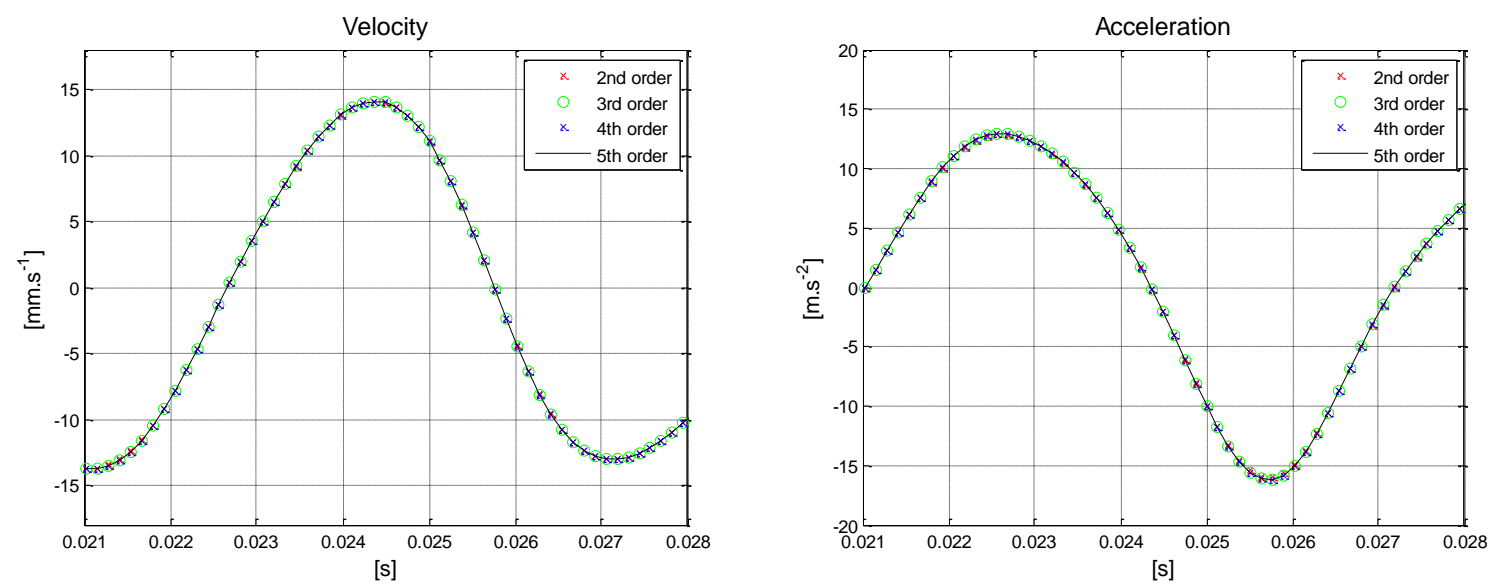

Source: Own.

Fig. 5: Details of velocities (left) and acceleration (right) computed with different central difference schemes

\subsection{Experiments with a shaker}

The shaker has been used in the following part of experiments. The purpose of this measurement is to determine the influence of the frequency on the accuracy of the optical method. The exciter LDS V200 coupled with the power amplifier LDS PA25E was chosen; the signal was generated in an analyzer platform Pulse by Brüel \& Kjær and sent to the power amplifier. The range of frequencies under investigation was chosen as an interval $f=$ $\langle 0,50\rangle \mathrm{Hz}$ with the discretization $\Delta f=5 \mathrm{~Hz}$. The acceleration was measured with the accelerometer DeltaTron 4519-002, which is a miniature piezoelectric accelerometer with the weight of only $1.6 \mathrm{~g}$. The signal was captured with the platform Pulse. The sampling frequencies of the accelerometer and the camera were setup to the identical value $f_{s}=$ $2048 \mathrm{~Hz}$ and the shutter time remained $t=30 \mu \mathrm{s}$. The optical target consisted of two black points in a constant distance and it is shown in the left-hand side part of Fig. 6. The acceleration was computed by using the central difference scheme of the 5 th order. The evaluated and measured signals were transformed to the frequency domain performing the Fourier transform and the resonant frequencies were compared to the exciting frequency. The frequencies are listed in Tab. 1. On the basis of the results it can be concluded that the results are convincing in all of the measured frequencies. The comparison of accelerations in the time domain is a plot for the exciting frequencies $f=\{5,15,35,45\} \mathrm{Hz}$ shown in Fig. 8.
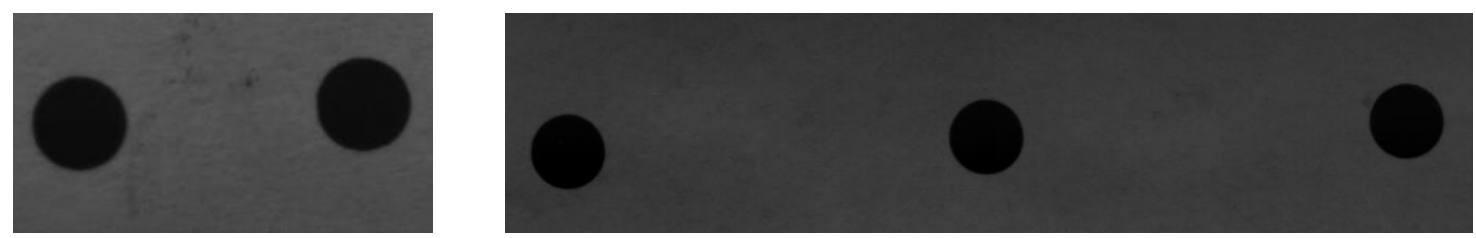

Source: Own.

Fig. 6: Optical targets used in the experiments. The target for the experiments with the shaker (left picture) and for the aeroelastic one (right picture).

Tab. 1: Frequencies of the motion in experiments with the shaker. All values are in Hertz.

\begin{tabular}{|l|l|l|l|l|l|l|l|l|l|l|}
\hline Shaker & 5 & 10 & 15 & 20 & 25 & 30 & 35 & 40 & 45 & 50 \\
\hline Accelerometer & 5 & 10 & 15 & 20 & 25 & 30 & 35 & 40 & 45 & 50 \\
\hline Optical measurement & 5 & 10 & 15 & 20 & 25 & 30 & 35 & 40 & 45 & 50 \\
\hline
\end{tabular}

Source: Own. 


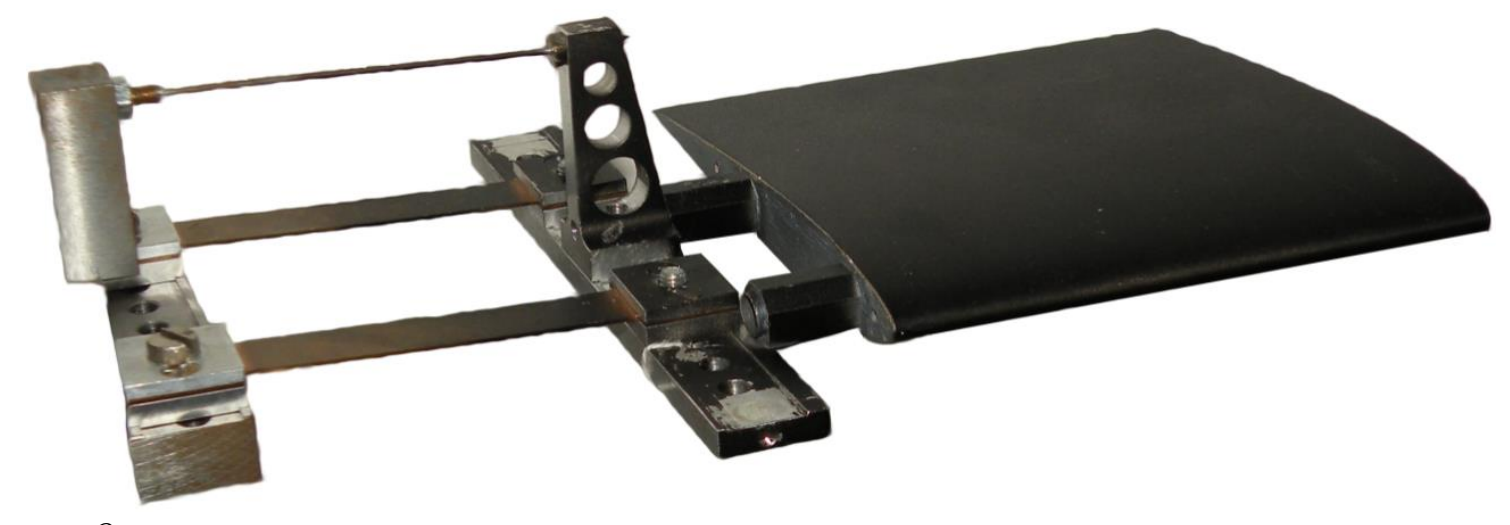

Source: Own.

Fig. 7: Experimental aeroelastic stand with the profile NACA 0012 attached to the ground with two degrees of freedom

\subsection{Experiment with aeroelastic stand}

The experiments were done with the profile NACA 0012 (Fig. 7) attached to the ground with two degrees of freedom, which are represented by two translations. This configuration is not usual in aeroelastic experiments; nevertheless, the optical methods can be verified there as well. The optical target is represented by three black points and it is shown in the right-hand side of Fig. 6. The three points in the case of two degrees of freedom introduce the redundancy. The acceleration was measured with the accelerometer DeltaTron 4519-002 for the comparison of the results. The free response of the system to an initial impulse was captured. The results of the redundant evaluation based on (1) are shown in Fig. 9, where the computed acceleration is compared with the measured one. The benefit of the redundant evaluation can be proved both in the time domain and the frequency domain as well. The accelerations in the frequency domain are covered in Fig. 10. The value measured with an accelerometer is considered to be a reference curve in our case. The peaks of resonant frequencies of the redundant evaluation are closer to the reference values than the peaks of standard evaluation. This comparison is proposed in relation to the fact that the calibrated industrial accelerometers are used as the standard acceleration sensors with high precision. On the basis of that graph it can be concluded that the redundant evaluation of the measurement produces a benefit in the form of a higher accuracy than a standard evaluation of the optical measurement. 

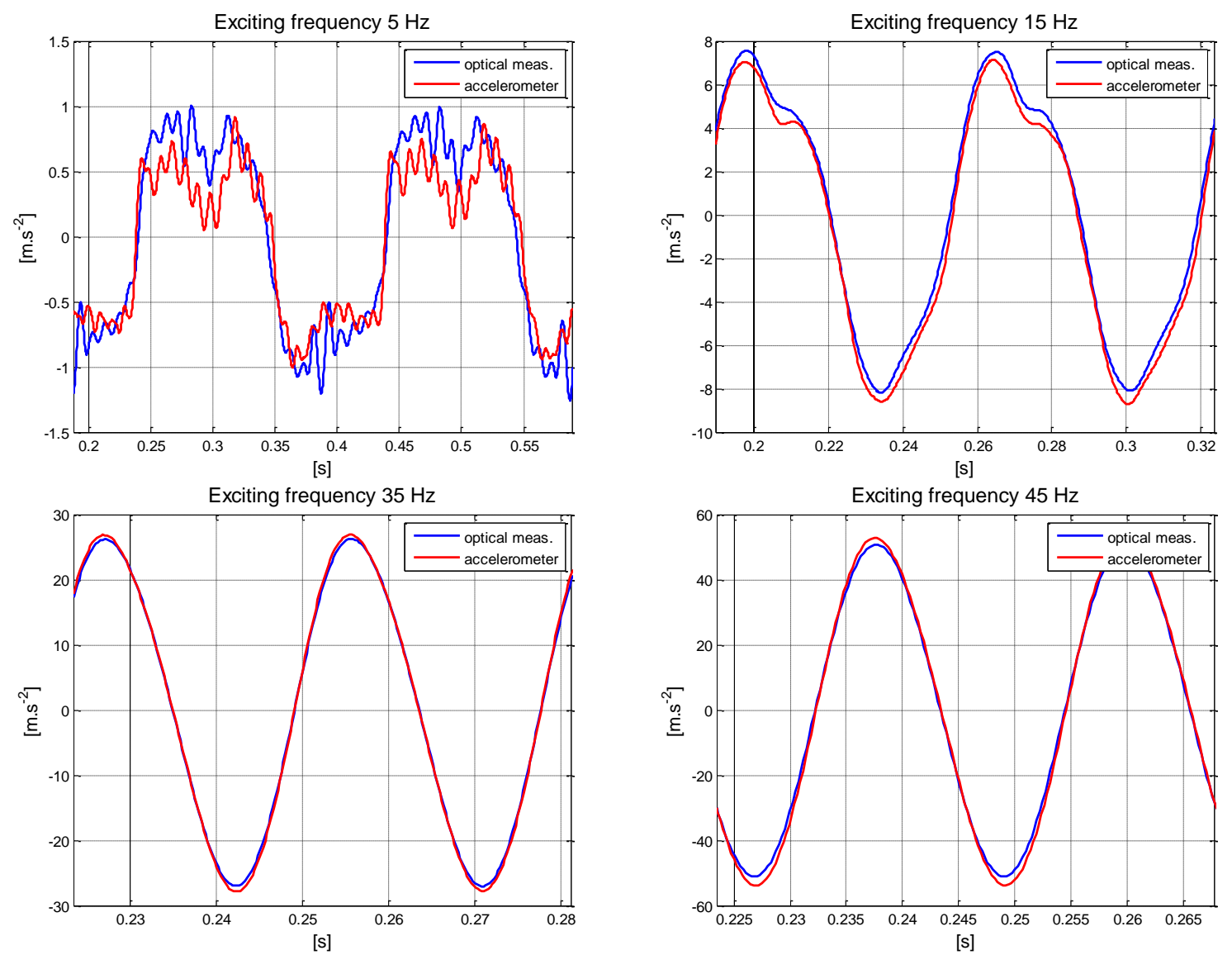

Source: Own.

Fig. 8: Comparison of acceleration measured with accelerometer (red line) and computed from the optical measurement (blue line)

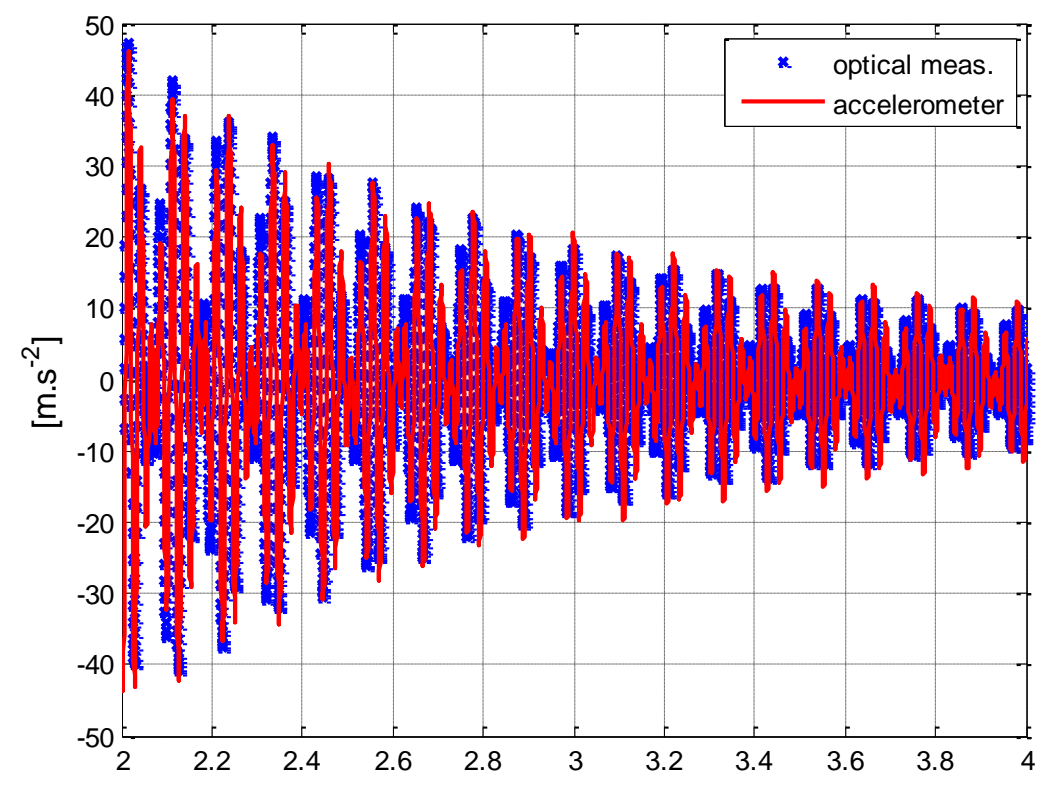

[s]

Source: Own.

Fig. 9: Comparison of the acceleration of the aeroelastic system measured with an accelerometer (red line) and computed from optical measurement (blue crosses) 


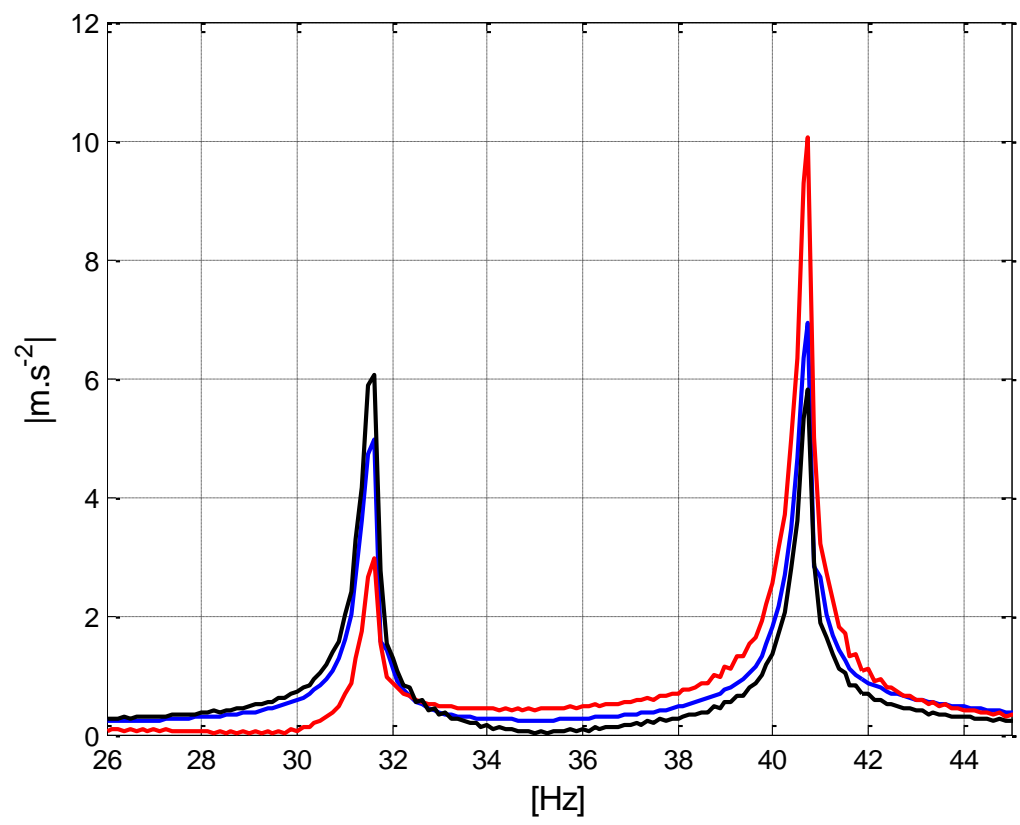

Source: Own.

Fig. 10: Comparison of acceleration in the frequency domain. Signal from the accelerometer (blue line), from the optical measurement (red line) and from the optical measurement with redundant evaluation of the signal (black line).

\section{Conclusion}

The presented paper describes an optical method usable in experiments for the measurement of kinematic quantities. Based on the presented graphs, it has been proved that the optical method is characterized by a high accuracy with a minimal influence over the SUT. A great advantage of the optical approach is the evaluation of both position and velocity. The redundant evaluation of the optical measurement refines the results, and due to the fact the redundancy is only a software tool without other direct costs, the redundant evaluation is recommended to be used. The improved measurement of the kinematic quantities makes the experiment more valuable and the results more applicable. The disadvantage of the presented method is the off line procedure and time consuming evaluation of the results.

Further work will be focused on the measurement of dynamics of the aeroelastic stand. The acting forces in aeroelastic experiments are typically measured with tensometric sensors, which are calibrated to the deviation and frequency. The idea is to leave out the tensometric sensors and to calibrate the force to the position and frequency. The position will be measured with an optical method; the frequency will be evaluated consequently. The force will be measured with a proper force transducer.

\section{Acknowledgements}

The research was supported by the project of the Grant Agency of the Czech Republic GA13$10527 \mathrm{~S}$, "Subsonic flutter analysis of elastically supported airfoils using interferometry and CFD”.

\section{Literature}

[1] FEISTAUER, M.; HORÁČEK, J.; RŮŽIČKA, M.; SVÁČEK, P.: Interaction of a flexibly supported airfoil and a channel flow. Engineering Mechanics. 2008, Vol. 15, No. 1. 
[2] CHLÁDEK, Š.; ZOLOTAREV, I.: Aerodynamic forces and kinematic properties measured on a fluttering profile. DYMAMESI 2014. Praha, 2014. ISBN 978-80-8701254-3.

[3] VLČEK, V.; KOZÁNEK, J.; ZOLOTAREV, I.: Flutter at a low velocity. Engineering Mechanics 2014. Svratka, 2014. ISBN 978-214-4871-1.

[4] HORÁČEK, J.; RADOLF, V.; BULA, V.; VESELÝ, J.; LAUKKANEN A. M.: Experimental investigation of air pressure, acoustic characteristics and vibrations of vocal folds on a complex physical model of phonation in humans. Engineering Mechanics 2013. Svratka, 2014. ISBN 978-80-87012-47-5.

[5] LEVEQUE, R. J.: Finite difference methods for ordinary and partial differentials equations. Society for Industrial and Applied Mathematics (SIAM), Philadelphia, 2007. ISBN 978-0-898716-29-0. 
Kvalitní aeroelastický experiment se zabývá klíčovými veličinami pro popis dynamiky aeroelastických jevi̊. Jsou jimi poloha, rychlost a zrychlení tělesa a síly, které je vyvolaly. $\mathrm{V}$ předkládaném článku je popsáno provedené měření kinematických veličin bezkontaktní metodou založenou na snímání optického terče vysokorychlostní kamerou. Z naměřeného průběhu polohy byly vypočteny hodnoty rychlosti a zrychlení tělesa, které byly porovnány $\mathrm{s}$ daty získanými akcelerometrem. Výhodou představeného optického měření je minimální ovlivnění měřeného systému a dále možnost redundantního měření zpřesňujícího získávané výsledky. Jeho př́nos je potvrzen experimentem na experimentálním aeroelastickém stojanu s leteckým profilem NACA 0012.

\section{AEROELASTISCHE EXPERIMENTE MIT DER MESSUNG VON KINEMATISCHEN VARIABLEN UNTER ANWENDUNG DER OPTISCHEN METHODEN}

Ein glaubwürdiges aeroelastisches Experiment befasst sich mit Schlüsselvariablen für die Beschreibung der Dynamik von aeroelastischen Phänomenen, z.B. die Position, die Geschwindigkeit und Beschleunigung des Körpers und die Kräfte, die sie hervorgerufen haben. Im vorliegenden Artikel wird eine Messung von kinematischen Phänomenen unter Anwendung der kontaktlosen Methode auf Basis einer Aufnahme der optischen Zielscheibe mit einer Hochgeschwindigkeitskamera beschrieben. Aus dem gemessenen Positionsverlauf wurden die Geschwindigkeits- und Beschleunigungswerte des Körpers berechnet, die mit den aus dem Beschleunigungsmesser gewonnenen Daten verglichen wurden. Bei der vorgestellten optischen Messung ist die minimale Beeinflussung des Messsystems und weiter die Möglichkeit der redundanten Messung, die die Ergebnisse noch präziser machen kann, von Vorteil. Der Beitrag dieser Messung wurde mit einem Experiment mit dem Flügel NACA 0012 bestätigt.

\section{EKSPERYMENTY AEROELASTYCZNE Z POMIAREM WIELKOŚCI KINEMATYCZNYCH PRZY ZASTOSOWANIU METODY OPTYCZNEJ}

Zaawansowany eksperyment aeroelastyczny dotyczy kluczowych wielkości służących do opisu dynamiki zjawisk aeroelastycznych. Należą do nich położenie, prędkość i przyspieszenie ciała oraz siły, które go spowodowały. W niniejszym artykule opisano wykonane pomiary wielkości kinematycznych przy pomocy metody bezkontaktowej opartej na rejestrowaniu tarczy optycznej przy pomocy kamery o wysokiej prędkości zapisu. Na bazie zarejestrowanego przebiegu położenia obliczono wartości prędkości i przyspieszenia ciała, które porównano $\mathrm{z}$ danymi uzyskanymi przy pomocy akcelerometra (przyspieszeniomierza). Zaletą zaprezentowanych pomiarów optycznych jest minimalny wpływ na system pomiarowy oraz możliwość redundancyjnego pomiaru precyzującego pozyskiwane wyniki. Ich korzyści potwierdzono w ramach eksperymentu na doświadczalnym aeroelastycznym statywie z profilem lotniczym NACA 0012. 